\title{
Soil organic matter fractions, chemical attributes and aggregation under forestry and agricultural systems
}

\author{
Cristiane Figueira da Silva', Marcos Gervasio Pereira'*, \\ Júlio César Feitosa Fernandes' ,Ariovaldo Machado Fonseca Júnior', \\ João Henrique Gaia-Gomes', Carlos Eduardo Gabriel Menezes* \\ 'Federal Rural University of Rio de Janeiro, Seropédica, RJ, Brasil. \\ ${ }^{2}$ Federal Institute of Education Science and Technology of Rio de Janeiro, Pinheiral, RJ, Brasil. \\ *Corresponding author, e-mail: mgervasiopereira01@gmail.com
}

\begin{abstract}
The aim of this work was to evaluate the influence of the conversion of forest systems to agricultural systems in the organic matter compartments, aggregation and soil chemical attributes, in the Atlantic Forest. The evaluated systems were: annual crop (ACr); perennial agriculture (PAg); pasture; and secondary forest early (SFES), medium (SFMS), and advanced stage (SFAS). Soil samples were collected at the layer of 0-5 cm depth and quantified the total organic carbon (TOC), C of humic substances, oxidizable $C$, granulometric fractions of soil organic matter (SOM), soil chemical attributes, soil aggregation and glomalin-related soil protein (GRSP-total and GRSP-easily extractable) in different aggregate classes. It was observed a reduction of the TOC, particulate organic carbon (POC), humic substances and oxidizable $C$ in the PAg and $\mathrm{ACr}$ areas comparing to pasture and forest systems. Moreover, the $\mathrm{pH}$ values increased whereas P content decreased in comparison with SFAS. As for aggregation, the PAg and the $\mathrm{ACr}$ decreased by around $35 \%$ and $20 \%$ the mean weight diameter of aggregates, respectively, compared to the average values found in the forestry systems, and $34 \%$ and $45 \%$, respectively in relation to pasture. In general, GRSP-total were reduced by agriculture. Thus, it appears that the agriculture which has been practiced is altering negatively the soil chemical, physical and biological attributes.
\end{abstract}

Keywords: particulate organic carbon, oxidizable fractions, humic substances, glomalin

\section{Introduction}

The conversion of a native forest area to intensive agricultural use can promote changes in soil physical, chemical and biological attributes (Lisbôa \& Miranda, 2014; Machado et al., 2014). The removal of the soil natural vegetal cover promotes a reduction of the vegetal material deposition, resulting in a decrease of the soil organic matter content (SOM) over time (Machado et al., 2014).

The SOM is constituted of different fractions that have different degrees of lability, which are not altered in the same magnitude when changes in the land use are carried out. Bernini et al. (2009) observed that the conversion of forest to pasture in Acre state, Brazil, promoted a reduction in total organic carbon (TOC) and particulate organic carbon (POC), whereas the oxidizable carbon fractions (F2 and F4) were not altered. According to the literature, (Loss et al. 2009; 2014a), the POC is effective to evaluate changes in OC contents which occur as result of agricultural management, especially at the first centimeters of the soil. On the other hand, Fontana et al. (2011), evaluating the SOM compartments in Atlantic Forest soils, observed that among the SOM fractions, the TOC was the most adequate fraction to show differences between soil use systems.

A more specific way to evaluate OC 
content and, consequently, the effect of land use and management practices on soil quality is related to the evaluation of humic substances (fulvic acids, humic acids and humina) (Fontana et al., 2011; Loss et al., 2014a; Machado et al., 2014). Humic substances (HS) constitute $85 \%$ to $90 \%$ of the total OM reserve, while at the same time being dynamic, reflecting changes in land use, HS are also one of the fractions responsible for the SOM accumulation (Paula et al., 2013).

Several studies consider $\mathrm{OM}$ and its fractions as the main agents for stabilization of soil aggregates (Bochner et al., 2008; Mandiola et al., 2011). According to some authors (Coutinho et al., 2010; Santos et al., 2012), higher soil $\mathrm{OC}$ content promotes greater stability of soil aggregates, and this, in turn, provides greater physical protection for the OM.

In forest areas the litterfall, in conjunction with the plant root system, continuously provides OM to the soil, which favors the maintenance of the microbial activity and biomass, as well as its diversity (Silva et al., 2012; Costa et al., 2015). Such conditions, over time, also directly influence the formation of soil aggregates that become more stable by having in their composition organic compounds binding the soil particles (Portugal et al., 2010).

The aim of this work was to evaluate the influence of the conversion of forest systems to agricultural systems in the organic matter compartments, aggregation, and soil chemical attributes, in the Atlantic Forest biome, in Pinheiral county, Rio de Janeiro state, Brazil.

\section{Materials and Methods}

The experiment was carried out in Pinheiral county, located in the region of "Médio Paraíba Fluminense", in the sub-basin of Cachimbal river. The area is located at the following coordinates: $22^{\circ} 33^{\prime} \mathrm{S}$ and $22^{\circ} 38^{\prime} \mathrm{S}$ latitudes and $43^{\circ} 57^{\prime} \mathrm{W}$ and $44^{\circ} 05^{\prime} \mathrm{W}$ longitudes. The climate of the region, according to Köppen's classification was identified as Am-Rainy, monsoon tropical climate with dry winter, where the mean temperature $\left({ }^{\circ} \mathrm{C}\right)$ and precipitation $(\mathrm{mm})$ values, from November 2009 to June 2010 , were $22.14^{\circ} \mathrm{C}$ and $57.50 \mathrm{~mm}$, respectively. Six areas were selected for carrying out this study, which were: secondary forest early stage (SFES), secondary forest medium stage (SFMS), secondary forest advanced stage (SFAS), pasture, perennial agriculture (PAg) and annual crops (ACr) (Table 1). All the areas are located in the upper third of hillside position, the soil was classified as "Cambissolo Háplico Tb Distrófico típico" (Inceptisol).

In each of the study areas a plot of $20 \mathrm{x}$ 20 meters was delimited, where soil samples were collected. In order to evaluate soil aggregation, five undisturbed samples were collected in the layer of $0-5 \mathrm{~cm}$ depth, using a cutting blade. For the evaluation of the soil organic matter and chemical attributes, in each area, three composite samples were collected at the layer of 0-5 cm depth, each composite sample was formed from five simple samples. After collection, the samples were air-dried, broken and passed through a $2.00 \mathrm{~mm}$ mesh sieve.

The soil chemical attributes $(\mathrm{pH}, \mathrm{P}, \mathrm{K}$, $\mathrm{Ca}, \mathrm{Mg}, \mathrm{Na}, \mathrm{Al}, \mathrm{H}+\mathrm{Al}$ e Valor $\mathrm{V}$ ) were analyzed according to Embrapa (1997), the total organic carbon (TOC) was analyzed according to Yeomans \& Bremmer (1988), and the SOM granulometric fractionation were determined according to Cambardella \& Elliott (1992), obtaining the particulate organic carbon (POC) and the mineral-associated carbon (MAC). About $20 \mathrm{~g}$ of soil and $60 \mathrm{~mL}$ of sodium hexametaphosphate solution $\left(5 \mathrm{~g} \mathrm{~L}^{-1}\right)$ were stirred for 15 hours on a horizontal shaking machine. The suspension was then passed through a $53 \mu \mathrm{m}$ sieve. The material retained on the sieve (POC) was dried at $50^{\circ} \mathrm{C}$ in a stove, quantified in relation to its mass, ground in a gral of porcelain and then analyzed for the TOC content (Yeomans \& Bremmer, 1988). The MAC was obtained from the difference between TOC and POC.

For the chemical fractionation of soil organic matter (SOM), the organic carbon content of the humina (C-HUM), humic acid (C-HAF) and fulvic acid (C-FAF) fractions were quantified according to the International Humic Substance Society (IHSS) (Swift, 1996).

The stability of aggregates was determined by the method of water-stable aggregates (Yooder, 1936).

Glomalin in soil aggregate classes (8-4, $4-2$, and $2-0,5 \mathrm{~mm}$ ) was quantified as glomalin- 
Table 1. History and description of land use systems in the region of "Médio Vale Paraíba do Sul", Rio de Janeiro state, Brazil

\begin{tabular}{ll}
\hline Abbreviation & \multicolumn{1}{c}{ History and description of the area(1) } \\
\hline SFES & $\begin{array}{l}\text { Secondary forest early stage: sparse forest cover, which is characteristic of an early- } \\
\text { Successional stage (CONAMA, 1994), originated by use of the area until 1985 with } \\
\text { spontaneous pasture, managed by annual cutting and occasional burnings, when it was } \\
\text { occupied by small farmers, who fenced the area, allowing then the forest regeneration. }\end{array}$ \\
& $\begin{array}{l}\text { Secondary forest medium stage: In a contiguous area at the same elevation as SFES area } \\
\text { and that until 1985, was covered by spontaneous pasture with the initial formation of } \\
\text { shrubbery vegetation (capoeira), being protected until the present day, which allowed the } \\
\text { development of the typical medium-successional stage. }\end{array}$ \\
\hline SFAS & $\begin{array}{l}\text { Secondary forest advanced stage: dense vegetal covering and better structured than } \\
\text { the previous ones, which allows to classify it in this successional stage. (CONAMA, 1994) - } \\
\text { probably the succession began after the decline in coffee production in the region and it } \\
\text { constitutes the oldest fragment in the lower portion of the sub-basin. }\end{array}$ \\
\hline Pasture & $\begin{array}{l}\text { It has been explored with spontaneous pasture since the 1950s and it was formed in the } \\
\text { 1990s with Brachiaria decumbens, and then maintained by annual cutting and controlled } \\
\text { burning - over the years resurfaced in this landscape the grass known as Bahia grass } \\
\text { (Paspalum notatum), which came to coexist with the brachiaria introduced. }\end{array}$ \\
\hline ACr & $\begin{array}{l}\text { Perennial agriculture: until the 1990s this area was used as pasture. After this period, this area } \\
\text { returned to be used for subsistence agricultural activities (corn and beans), in the present } \\
\text { day it is cultivated with citrus. The conventional system of soil preparation is used (without } \\
\text { fertilization and liming), with periodical manual weeding. }\end{array}$ \\
\hline $\begin{array}{l}\text { Annual crops: it has been used for subsistence agricultural activities (corn, beans, cassava) } \\
\text { for approximately 20 years, which is cultivated with cassava in this present days. The } \\
\text { conventional system of soil preparation is used (without fertilization and liming), with } \\
\text { periodical manual weeding. }\end{array}$ \\
\hline
\end{tabular}

Silva et al. (2012) adapted by Menezes (2008)

related soil protein (GRSP). Two fractions of GRSP (easily extractable glomalin - EEG; total glomalin - TG) were distinguished according to the extraction conditions (Rillig, 2004). The easily extractable glomalin was obtained from the autoclave extraction using 1 gram of soil sample and $8 \mathrm{~mL}$ of $20 \mathrm{mM}$ sodium citrate solution, $\mathrm{pH}$ 7.4 , at a temperature of $121^{\circ} \mathrm{C}$ for $30 \mathrm{~min}$. The total glomalin content was obtained using 1 gram of soil sample and $8 \mathrm{~mL}$ of $50 \mathrm{mM}$ sodium citrate, $\mathrm{pH} 8.0$, at $121^{\circ} \mathrm{C}$ for $60 \mathrm{~min}$. For extraction of this fraction, more than one autoclaving cycle (3 to 13 cycles depending on the sample) was required until the sample color was that of light yellow. In both fractions, after autoclaving, centrifugations were performed at $5000 \mathrm{~g}$ for $20 \mathrm{~min}$, which the supernatant was removed for subsequent quantification of protein. The quantification of glomalin was performed by the Bradford method (Wright et al., 1996), available at www.usda.gov, using bovine serum albumin. The GRSP concentrations for both fractions were corrected to $\mathrm{mg} \mathrm{g}^{-1}$ of soil, considering the total volume of supernatant and the dry soil mass.

The data were evaluated for homoscedasticity, by the Cochran test and normal distribution of residues, by the Lilliefors test. Subsequently, the data were submitted to analysis of variance and the Bonferroni t-test, at $5 \%$ of probability. The relationships between soil attributes were determined by Pearson's correlation analysis. These tests and analyses were carried out using SAGE-5.0 statistical software (Sistema de Análises Estatísticas e Genéticas - Universidade Federal de Viçosa) and SISVAR-5.0 statistical software. Principal component analysis (PCA) was performed using PAST software (Paleontological Statistics Software Package for Education and Data Analysis), with the variables whose correlation with the F1 and F2 axes were $\geq 0,70$. This analysis was used to reduce the dimensions of the data and, consequently, to facilitate the analysis by the correlation circle graph (Pearson). 


\section{Results and Discussion}

Soil Organic Matter Fractions

Soil use systems with annual crops and perennial agriculture promoted reductions in the total organic carbon (TOC) content, which were $28 \%$ and $38 \%$, respectively, in relation to the average value found in the forest systems (TOC = $23.01 \mathrm{~g} \mathrm{~kg}^{-1}$ ). There were no significant changes in the TOC content between forest and pasture areas (Table 2). However, it was found that pasture showed TOC contents, about $43 \%$ and $69 \%$ higher than $\mathrm{PAg}$ and $\mathrm{ACr}$, respectively.
The highest POC values were observed in the SFMS and pasture areas, followed by SFAS and SFES areas, whereas the lowest POC values were found in the agricultural areas (Table 2). It was verified that the POC values in the SFMS were $249 \%$ and $364 \%$ higher than in those found in the PAg and Acr areas, respectively. Loss et al. (2009) studying areas with different vegetation covers, verified that the POC content showed higher values in the areas where the greatest deposition of plant residues occurred.

Table 2. Total organic carbon (TOC), C of humic substances, oxidizable $C$ and SOM granulometric fractions ( $\mathrm{g} \mathrm{kg}-1$ ) of a Cambissolo Háplico (Inceptisol) under agricultural systems (Annual crops - Acr; and perennial - PAg), pasture and secondary forest in three successional stage (Advanced - SFAS; Medium - SFMS; and Early - SFES), at the layer of $0-5 \mathrm{~cm}$ depth.

\begin{tabular}{|c|c|c|c|c|c|c|}
\hline \multirow{2}{*}{ Fractions } & \multicolumn{6}{|c|}{ Agricultural systems } \\
\hline & SFAS & SFMS & SFES & Pasture & PAg & Acr \\
\hline TOC & $21.17 a$ & $23.67 a$ & $24.20 a$ & $23.88 a$ & $16.70 \mathrm{~b}$ & $14.18 b$ \\
\hline POR & $7.22 b$ & $10.91 a$ & $8.27 b$ & $10.29 a$ & $3.12 \mathrm{c}$ & $2.35 c$ \\
\hline MAC & $13.94 a$ & $12.76 a$ & $15.93 a$ & $13.60 a$ & $13.60 a$ & $11.83 a$ \\
\hline C-HUM & $14.05 a$ & $12.32 \mathrm{~b}$ & $12.72 b$ & $12.77 b$ & $8.19 c$ & $6.53 d$ \\
\hline $\mathrm{C}-\mathrm{HAF}$ & $2.79 a$ & $2.19 a$ & $1.21 \mathrm{~b}$ & $2.58 a$ & $1.49 \mathrm{~b}$ & $1.09 b$ \\
\hline C-FAF & $3.85 a$ & $2.88 \mathrm{~b}$ & $4.30 a$ & $3.41 a$ & $2.20 c$ & $1.58 \mathrm{c}$ \\
\hline F1 & $5.01 a$ & $4.79 a$ & $5.69 a$ & $4.79 a$ & $2.98 b$ & $2.95 b$ \\
\hline F2 & $3.04 b$ & $3.46 b$ & $1.71 \mathrm{c}$ & $5.88 a$ & $3.00 \mathrm{~b}$ & $1.78 \mathrm{c}$ \\
\hline F3 & $7.07 a$ & $5.24 a$ & $5.24 a$ & $5.20 a$ & $1.53 \mathrm{~b}$ & $1.17 \mathrm{~b}$ \\
\hline $\mathrm{F} 4$ & $4.64 a$ & $3.50 a$ & $3.80 a$ & $3.36 a$ & $1.63 b$ & $1.17 \mathrm{~b}$ \\
\hline
\end{tabular}

The lowest COP values in the agricultural areas may result in changes in the stability of the macroaggregates (> $250 \mu \mathrm{m}$ ) and negatively reflect the soil resistance to external pressures (Loss et al., 2014a; Blair, 2000). Therefore, the soil can become more sensitive to compaction and more susceptible to erosive processes (Loss et al., 2014a).

By observing the POC average values it was possible to note differences between the three forest areas evaluated. This same pattern was not observed for the TOC content, where the areas of SFAS and SFES were statistically the same as the SFMS area (Table 2). This fact shows that POC was more efficient in identifying changes caused by the different stages of regeneration. Loss et al. (2009) observed that the POC was a more sensitive indicator comparing to the TOC to detect differences between types of soil management. According to Heide et al. (2009), since POC is a labile fraction with a higher recycling rate of the organic constituents, the changes in their stocks promoted by soil management are usually perceived in the shortterm, whereas the TOC takes a longer time. There were no significant differences in the mineralassociated carbon (MAC) content in the studied areas (Table 2).

About the alkaline-soluble fractions, it was observed that the highest average values of C-HUM and C-HAF were found, in general, in the forest and pasture areas, and this could be related to the quality of the vegetal material, litterfall, and root contribution of grasses. Moreover, in these areas, due to the non-mobilization of the soil, organic matter is possibly more preserved. On the other hand, the lowest carbon content associated with the humic substances were verified in the ACr and PAg areas, which may be due to a greater soil mobilization, which possibly intensifies the SOM mineralization (Cunha et al., 2012; Silva et al., 2012), disfavoring the formation of humic substances.

For the oxidizable fractions, it was 
verified that the $\mathrm{F} 2$ fraction was the only one, among the others fractions, that showed a difference between the forest systems, showing the highest values in the SFAS and SFME areas. No significant differences were found for the $\mathrm{Fl}$, F3, and F4 fractions between forest systems and pasture, whereas values found for F2 fraction that was higher in the pasture area. All oxidizable fractions decreased their values when passing from forest systems and pasture to agricultural systems, except for the F2 fraction that did not show differences between SFAE, SFME, and PAg. This shows that the management adopted in these areas is contributing to the change in the TOC content and consequently to the oxidizable fractions.

\section{Soil chemical attributes}

For the soil chemical attributes, the $\mathrm{pH}$ values showed differences between areas, which were lower in the SFAE comparing to the other areas (Table 3). This pattern may be due to the highest values of Al content and potential acidity $(\mathrm{H}+\mathrm{Al})$ found in the SFAE area in relation to the others.

Table 3. Soil chemical attributes of a Cambissolo Háplico (Inceptisol) under agricultural systems (Annual crops - Acr; and perennial-PAg), pasture and secondary forest in three successional stage (Advanced -SFAS; Medium - SFMS; and Early - SFES), at the layer of 0-5 cm depth.

\begin{tabular}{lccccccccc}
\hline \multirow{2}{*}{ Areas } & $\mathrm{pH}$ & $\mathrm{P}$ & $\mathrm{K}$ & $\mathrm{Ca}$ & $\mathrm{Mg}$ & $\mathrm{Na}$ & $\mathrm{Al}$ & $\mathrm{H}+\mathrm{Al}$ & $\mathrm{V}$ \\
\cline { 2 - 9 } & \multicolumn{7}{c}{$\mathrm{mg} \mathrm{dm}^{-3}$} & \multicolumn{7}{c}{$0-5 \mathrm{~cm}$} \\
\cline { 2 - 9 } & $4.08 \mathrm{c}$ & $19.52 \mathrm{a}$ & $0.18 \mathrm{c}$ & $2.33 \mathrm{~b}$ & $1.07 \mathrm{c}$ & $0.03 \mathrm{a}$ & $1.07 \mathrm{a}$ & $7.00 \mathrm{a}$ & $34 \mathrm{c}$ \\
\hline SFAS & $5.89 \mathrm{a}$ & $11.15 \mathrm{~b}$ & $0.59 \mathrm{a}$ & $5.27 \mathrm{a}$ & $3.47 \mathrm{a}$ & $0.05 \mathrm{a}$ & $0.00 \mathrm{c}$ & $5.77 \mathrm{~b}$ & $62 \mathrm{a}$ \\
SFMS & $5.82 \mathrm{a}$ & $14.56 \mathrm{a}$ & $0.39 \mathrm{~b}$ & $2.03 \mathrm{~b}$ & $1.77 \mathrm{~b}$ & $0.05 \mathrm{a}$ & $0.60 \mathrm{~b}$ & $7.23 \mathrm{a}$ & $37 \mathrm{c}$ \\
SFES & $5.21 \mathrm{~b}$ & $15.49 \mathrm{a}$ & $0.63 \mathrm{a}$ & $3.07 \mathrm{~b}$ & $3.77 \mathrm{a}$ & $0.05 \mathrm{a}$ & $0.07 \mathrm{c}$ & $5.97 \mathrm{~b}$ & $55 \mathrm{~b}$ \\
Pasture & $5.49 \mathrm{~b}$ & $8.20 \mathrm{~b}$ & $0.23 \mathrm{c}$ & $1.80 \mathrm{~b}$ & $3.43 \mathrm{a}$ & $0.06 \mathrm{a}$ & $0.17 \mathrm{c}$ & $4.47 \mathrm{c}$ & $55 \mathrm{~b}$ \\
Acr & $5.42 \mathrm{~b}$ & $8.82 \mathrm{~b}$ & $0.20 \mathrm{c}$ & $2.27 \mathrm{~b}$ & $2.40 \mathrm{~b}$ & $0.06 \mathrm{a}$ & $0.10 \mathrm{c}$ & $4.53 \mathrm{c}$ & $55 \mathrm{~b}$ \\
PAg & Average values sharing the same lefter do not differ by Scott-Knott test at 5\%.
\end{tabular}

No significant variations were observed in

Ca contents between the agricultural areas and the SFAE and SFES. On the other hand, there was a reduction of $\mathrm{Ca}$ and $\mathrm{K}$ contents (around $60 \%$ ) in the areas of agricultural activity compared to the SFME area. The pasture area showed significantly higher $\mathrm{K}, \mathrm{Ca}$ and $\mathrm{Mg}$ contents than the forest systems in the advanced and early successional stages (Table 3). Losset al. (2014a) also observed higher contents of these nutrients in pasture area in relation to the native forest, in an Argisol (Ultisol), in Acre state, Brazil.

The agricultural and pasture areas showed higher saturation values (V) than the forest fragments in the early and advanced successional stages (Table 3). This pattern indicates that vegetation nutrition in forests is supported, possibly, by the nutrients cycling, with great accumulation of the organic matter, being released gradually by the roots and branches decomposition and then incorporated into the soil (Barreto et al., 2006).

Lower $\mathrm{P}$ values were found in the $\mathrm{ACr}$ and PAg areas comparing to the forest areas (advanced and early stage) and the pasture area (Table 3). This pattern may be related to a reduction in soil organic matter content in agricultural areas (Machado et al., 2014).

\section{Soil aggregation}

The mean weight diameter (MWD) of the soil aggregates ranged from 2.71 to $4.92 \mathrm{~mm}$, the lowest value was observed in the PAg area and the highest one in the pasture area. The geometric mean diameter (GMD) showed the same results as the MWD $(1.96$ to $2.50 \mathrm{~mm}$ in PAg and pasture areas, respectively), although the difference was not significant. It can be observed that the PAg and the $\mathrm{ACr}$ reduced the MWD of the soil aggregates by $35 \%$ and $20 \%$, respectively, in relation to the average values $(4.14 \mathrm{~mm})$ found in the forest systems, and $34 \%$ and $45 \%$, respectively, in relation to average values of the pasture area (Table 4). This pattern may be related to the lowest increment of the TOC observed in the agricultural areas, addition to the exposure of the soil to the more intense impact of various elements, comparing to the forest and 
Table 4. Soil Aggregate stability indexes of a Cambissolo Háplico (Inceptisol) under agricultural systems (Annual crops - Acr; and perennial - PAg), pasture and secondary forest in three successional stage (Advanced - SFAS; Medium - SFMS; and Early - SFES), at the layer of 0-5 cm depth.

\begin{tabular}{lcc}
\hline \multirow{2}{*}{ Areas } & MWD & GMD \\
\cline { 2 - 3 } & & Mm \\
\hline SFAS & $4.22 \mathrm{a}$ & $2.29 \mathrm{a}$ \\
SFMS & $3.88 \mathrm{a}$ & $2.20 \mathrm{a}$ \\
SFES & $4.32 \mathrm{a}$ & $2.14 \mathrm{a}$ \\
Pasture & $4.92 \mathrm{a}$ & $2.50 \mathrm{a}$ \\
Acr & $3.27 \mathrm{~b}$ & $2.24 \mathrm{a}$ \\
PAg & $2.71 \mathrm{~b}$ & $1.96 \mathrm{a}$ \\
\hline Average values sharing the same letter do not differ by Bonferroni test at 5\%. MWD - mean weight diameter; GMD - geometric mean diameter.
\end{tabular}

pasture systems (Loss et al., 2014b). Evaluating soil aggregation and organic matter in different soil use systems, in Paraná state, Brazil, Loss et al. (2014b) observed that the agricultural activity (conventional tillage) reduced the aggregation indexes (MWD and GMD) when compared to the forest and pasture areas.

The vegetation is one of the factors that directly interfere in the soil carbon contents and its aggregation, due to the deposition of deciduous material to the soil, in addition to the cementing effect of root exudates and its mechanical action. (Beldini et al., 2010) The forest systems (SFES, SFME, SFAE) have denser (ranging from partially closed to closed) and larger vegetation (herb-shrub, shrub-tree) (Menezes, 2008), when compared to agricultural areas, thus, they have higher deposition of litterfall, and as a consequence, a larger increase of $\mathrm{C}$ to the soil, which promotes better aggregation indexes.

Significant and positive correlations were observed at $5 \%$ probability level between the MWD and TOC ( $r=0.90)$, as well as with some of the SOM compartments (POC, $r=083$; C-Hum, $r=0,89$; C-FAF, $r=0,85 ; F 1, r=0,83 ; F 3=0,82$; e F4, $r=0,80)$, whereas the GMD correlated only with F2 fraction $(r=0,90)$. Nobre et al. (2015) observed positive correlations between aggregation indexes (GMD and MWD) and the TOC and POC contents.

The three forest systems showed similar values for the GMD and MWD. It was verified that the soils in the different areas showed aggregation indexes (MWD) higher than 0.55 $\mathrm{mm}$. Soares et al. (2005) state that aggregates with the MWD values higher than this value 10.55 $\mathrm{mm}$ ) are relatively more resistant to breaking and dispersion, resulting in lesser susceptibility to changes in soil characteristics when subjected to a correct management.

Glomalin-related soil protein in soil aggregate classes

The GRSP (easily extractable glomalin EEG; total glomalin - TG) in three different classes of aggregates (C1, C2, and C3), as well as the average of the three classes in each area, can be visualized in Table 5. In relation to the EEG contents, it was verified that there was no difference between the areas in each class of aggregates (C1, C2, and C3), not even when the average of classes was observed. However, the pasture (C2 and C3) and ACr areas (C3) showed lower contents of this fraction in the lowest classes of soil aggregates.

Significant differences were observed for the TG between the areas within each class of soil aggregates, except for class C2, and also when the average of the classes in each area was performed. In relation to the classes average, greater increases in this fraction were observed in the areas in later successional stages (SFAE and SFME), as well as in the classes $\mathrm{Cl}$ and C3. Higher TG contents in these areas may be related to the accumulation of this protein over time, since it presents high soil stability (Rillig et al., 2004). Moreover, the highest TG contents in these forest systems when compared to the agricultural areas may have contributed to the highest values of soil carbon in these areas, since glomalin, through the formation of soil aggregates, plays an important role in soil carbon storage (Rillig et al., 2004).

There were differences between the soil aggregate classes only in the pasture and SFES areas, with $\mathrm{C} 1$ and $\mathrm{C} 2$, whose aggregates size 
Table 5. Total glomalin (TG) and easily extractable glomalin (EEG) in soil aggregate classes of a Cambissolo Háplico (Inceptisol) under agricultural systems (Annual crops - Acr; and perennial-PAg), pasture and secondary forest in three successional stage (Advanced - SFAS; Medium - SFMS; and Early - SFES), at the layer of 0-5 cm depth.

\begin{tabular}{ccccccc}
\hline \multirow{2}{*}{ Classes } & SFAS & SFMS & SFES & Pasture & PAg & Acr \\
\cline { 2 - 7 } & \multicolumn{7}{c}{ EEG $\left(\mathrm{mg} \mathrm{g}^{-1}\right.$ soil) } \\
\hline $\mathrm{C} 1$ & $1.34 \mathrm{aA}$ & $1.42 \mathrm{aA}$ & $1.59 \mathrm{aA}$ & $2.27 \mathrm{aA}$ & $1.86 \mathrm{aA}$ & $1.67 \mathrm{aA}$ \\
$\mathrm{C} 2$ & $1.26 \mathrm{aA}$ & $1.79 \mathrm{aA}$ & $2.21 \mathrm{aA}$ & $1.68 \mathrm{bA}$ & $1.49 \mathrm{aA}$ & $1.71 \mathrm{aA}$ \\
$\mathrm{C} 3$ & $1.67 \mathrm{aA}$ & $1.73 \mathrm{aA}$ & $1.56 \mathrm{aA}$ & $1.27 \mathrm{bA}$ & $1.19 \mathrm{aA}$ & $0.90 \mathrm{bA}$ \\
Mean & $1.42 \mathrm{~A}$ & $1.65 \mathrm{~A}$ & $1.79 \mathrm{~A}$ & $1.74 \mathrm{~A}$ & $1.51 \mathrm{~A}$ & $1.43 \mathrm{~A}$ \\
\hline \multicolumn{7}{c}{$\mathrm{TG}\left(\mathrm{mg} \mathrm{g}^{-1}\right.$ soil) } \\
\hline $\mathrm{Cl}$ & $4.84 \mathrm{aC}$ & $6.99 \mathrm{aA}$ & $6.21 \mathrm{aB}$ & $5.59 \mathrm{aB}$ & $3.92 \mathrm{aC}$ & $4.59 \mathrm{aC}$ \\
$\mathrm{C} 2$ & $6.97 \mathrm{aA}$ & $6.82 \mathrm{aA}$ & $5.73 \mathrm{aA}$ & $6.10 \mathrm{aA}$ & $5.94 \mathrm{aA}$ & $5.68 \mathrm{aA}$ \\
$\mathrm{C} 3$ & $4.78 \mathrm{aA}$ & $5.64 \mathrm{aA}$ & $3.56 \mathrm{bB}$ & $3.07 \mathrm{bB}$ & $3.03 \mathrm{aB}$ & $3.01 \mathrm{aB}$ \\
Mean & $5.53 \mathrm{~B}$ & $6.48 \mathrm{~A}$ & $5.17 \mathrm{C}$ & $4.92 \mathrm{C}$ & $4.30 \mathrm{C}$ & $4.43 \mathrm{C}$ \\
\hline Average values sharing the same letter do not differ by Scott-Knott test at 5\%. C= Size class of soil aggregates; $\mathrm{Cl}=8-4 \mathrm{~mm} ; \mathrm{C}=4-2 \mathrm{~mm} ; \mathrm{C}=2-0.5 \mathrm{~mm}$.
\end{tabular}

have larger diameters, with higher TG values. This pattern may be an indication of the participation of this protein in the formation and stabilization of soil aggregates, although no significant correlations were observed between glomalin fractions and aggregation indexes. These data agree with those found by Wright et al. (2007), who evaluated glomalin in different size classes of soil aggregates in a no-tillage system, observed that the glomalin contents increased parallel to the increase of the soil aggregates size.

In the C3 class of aggregates, it was verified that the EEG content showed positive correlations ( $5 \%$ of significance) with four (C-HUM, $r=0.86, F 1, r=0.80, F 3, r=0.85, F 4, R=0.80$ ) of out the ten SOM compartments evaluated. On the other hand, in classes $\mathrm{C} 1$ and $\mathrm{C} 2$, only the TG showed significant correlations ( $5 \%$ of significance), and these correlations were with the POC $(r=085)$ and C-FAF ( $r=0.82)$, respectively. Nobre et al. (2015) observed high correlations of EEG and TG with $\mathrm{OCD}$ and POC. According to these authors, the contribution of glomalin to the soil carbon stock and carbon sequestration is evident (BáezPérez et al., 2010). The high correlations observed between glomalin and carbon suggest that this protein contributes, directly, to the soil carbon pool (Nobre et al., 2015 ).

\section{Principal component analysis}

As a tool to distinguish the evaluated areas, two principal components (Factor 1 and Factor 2) were obtained for the soil chemical, physical and biological attributes (Figure 1). It was observed that the distribution of the selected variables showed accumulated variance of
$87.94 \%$ for the $\mathrm{F} 1$ and $\mathrm{F} 2$ axes, respectively. The $\mathrm{F} 1$ and $\mathrm{F} 2$ axes were able to explain $63.45 \%$ and $24.49 \%$ of this variance, respectively (Figure 1 ). The Fl axis was able to separate the SFAE, SFMS, SFES and pasture areas from the $\mathrm{ACr}$ and PAg areas. The variables that contributed most to this separation were C-HUM, C-FAF, Fl, F3 and $\mathrm{F} 4$ fractions, $\mathrm{P}$ content, and $\mathrm{H}+\mathrm{Al}$ content, since they showed the highest values of correlation coefficients with the Fl axis $(r \geq 0.90)$. The variables that contributed most to the $\mathrm{F} 2$ axis were $\mathrm{K}$ and $\mathrm{Mg}$ content, with correlation coefficients higher than 0.80 .

It can be observed that the areas showed distinct separations, dividing into two groups (Figure 1). The first group consisted of the agricultural areas, which was positioned in the lower left quadrant, that is, opposite from the disposition of most variables used in this analysis, as well as from the other study areas (Figure 1). The second group, formed by the pasture, SFAS, SFMS and SFES areas, is located in the upper right quadrant (pasture and SFMS) and in the lower right quadrant (SFAS and SFES) of the dendrogram, being more related to the soil chemical, physical and biological attributes.

Thus, the negative influence of agricultural activity under the aforementioned soil attributes is verified. This fact may be due to the lowest rates of deposition of plant material by these systems, resulting in a low incorporation of organic matter into the soil, which may reflect in low $\mathrm{C}$ contents in its different compartments, as well as lower aggregation indexes and biological activities, represented in this work by MWD and glomalin, respectively. In addition, the 


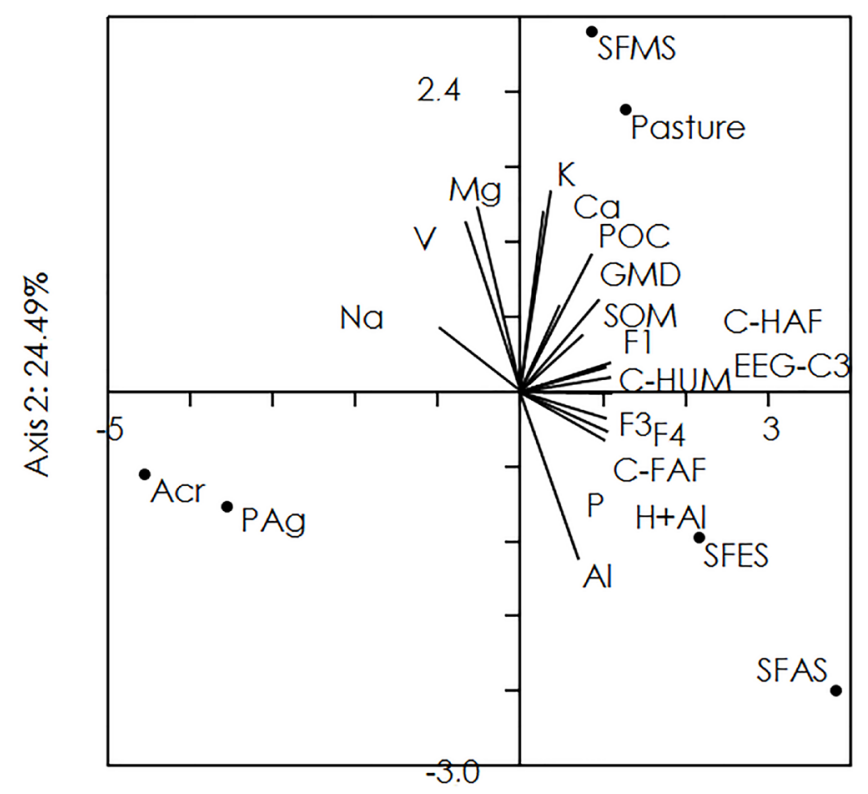

Axis 1: $63.45 \%$

Figure 1. Principal component analysis dendrogram (B) of soil physical, chemical and biological attributes of a Cambissolo Háplico (Inceptisol) under agricultural systems (Annual crops - Acr; and perennial - PAg), pasture and secondary forest in three successional stage (Advanced SFAS; Medium - SFMS; and Early - SFES), at the layer of 0-5 cm depth.

soil mobilization in the topsoil layer by successive weeding makes the organic matter more susceptible to microbial attack, which increases the mineralization rate of this layer (Cunha et al., 2012; Silva et al., 2012).

Assessing soil physical, chemical and total organic carbon in areas of annual agriculture (cassava) and forest systems (Secondary Forest, shrubbery vegetation -Capoeira, and banana in a crop-forest integration systems), in the Atlantic Forest biome, Silva et al. (2006) verified, through principal component analysis, separation between the agricultural system and the forest systems, whereby the chemical variables and the TOC were more related to forest systems, as observed in this present study.

\section{Conclusions}

The conversion of forest to agriculture results in an expressive decline in the contents of the soil organic matter compartments, accelerating the mineralization process, disfavoring the formation of the humic substances. In addition, it reduces the P content, soil aggregation index (MWD), and soil protein content related to glomalin.

\section{Acknowledgment}

To CNPq (National Council of Scientific Researches) for providing a scholarship to the first author. TO FAPERJ and the Graduate Program in Agronomy-Soil Science by their financial support.

\section{References}

Báez-Pérez,A.,Gonzalez-Chavez, M. C. A., Etchevers-Barra, J. D., Prat Christian, HidalgoMoreno C. 2010. Glomalin and carbon sequestration in cultivated tepetates = Glomalina secuestro de carbono entepetates cultivados. Agrociencia 44:517-529.

Barreto, A. C., Lima, F. H. S., Freire, M. B. G. S., Araújo, Q. R., Freire, R.A. 2006. Características químicas e físicas de um solo sob floresta, sistema agroflorestal e pastagem no sul da Bahia. Caatinga 19:415-425.

Beldini, T. P., Mcnabb, K. L., Lockaby, B. G., Sanchez, F. G., Navegantes-Câncio, O. 2010. The effect of Amazonian Eucalyptus plantations on soil aggregates and organic matter density fractions. Soil Use and Management 26:53-60.

Bernini, T.A., Loss, A., Pereira, M.G, Coutinho, F.S, Zatorre, N.P., Wadt, P.G.S. 2009. Frações Granulométricas e Oxidáveis da Matéria Orgânica do Solo em Sucessão Floresta - Pastagem no Acre. Revista Brasileira de Agroecologia 4:4334-4338. 
Blair,N.2000. Impact of cultivation and sugar cane green trash management on carbon fraction sand aggregat estability for a Chromic Luvisol in Queensland, Australia. Soil\&TillageResearch 55:183-191.

Bochner, J.K., Fernandes, M.M., Pereira, M.G. Balieiro, F.C., Santana, I.K.S. 2008. Matéria orgânica de um planossolo sob diferentes coberturas florestais. Cerne 14:46-53.

Cambardella, C.A., Elliott, E.T. 1992. Particulate soil organic-matter changes across a grassland cultivation sequence. Soil Science Society of America Journal 56:777-783.

Costa, J.T.F., Silva, L.S., Alves, A.R., Holanda, A.C., Leite, E.M., Nunes, A.K.A. 2015. Avaliação da serapilheira em área de mata ciliar na bacia do rio Gurguéia sul do Piauí. Revista Verde de Agroecologia e Desenvolvimento Sustentável10:13-19.

Coutinho, F. S., Loss, A., Pereira, M. G. Rodrigues Juniot, D. J., Torres, J. L. R. 2010. Estabilidade de agregados e distribuição do carbono em Latossolo sob sistema plantio direto em Uberaba Minas Gerais. ComunicataScientiae 1: 100-105.

Cunha, E.Q., Stone, L.F., Ferreira, E.P.B., Didonet, A.D., Moreira, J.A.A. 2012. Atributos físicos, químicos e biológicos de solo sob produção orgânica impactados por sistemas de cultivo. Revista Brasileira de Engenharia Agrícola e Ambiental 16:56-63.

Embrapa. Centro Nacional de Pesquisa de Solos. 1997. Manual de métodos de Análise de solo. EMBRAPA/SNLCS. Rio de Janeiro. 212p.

Fontana, A.F., Silva, C.F., Pereira, M.G., Loss, A., Brito, R.J., Benites, V.M. 2011. Avaliação dos compartimentos da matéria orgânica em área de Mata Atlântica. Acta Scientiarum. Agronomy 33:545-550.

Heide, D. M., Vitorino, A. C. T., Tirloni, C., Hoffmann, N.T.K. 2009. Frações orgânicas e estabilidade dos agregados de um Latossolo Vermelho Distroférrico sob diferentes usos. Revista de Ciências Agrárias 51:143-160.

Lisbôa, F.M., Miranda, P.B. 2014. Análise de atributos físicos e químicos de solo submetido a diferentes manejos no sudeste paraense. Agroecossistemas 6:1-9.

Loss, A., Costa, E.M., Pereira, M.G., Beutler, S.J. 2014b. Agregação, matéria orgânica leve e carbono mineralizável em agregados do solo. Revista de laFacultad de Agronomía. La Plata 113:1-8.

Loss, A., Pereira, M.G, Bernini, T.A, Zatorre, N.P. Wadt, P.G.S. 2014a. Fertilidade do solo e matéria orgânica em Vertissolo e Argissolo sob cobertura florestal e pastagem. ComunicataScientiae 5: 01-10.

Loss, A., Pereira, M.G., Schultz, N., Anjos, L.H.C., Silva, E.M.R. 2009. Carbono e frações granulométricas da matéria orgânica do solo sob sistemas de produção orgânica. Revista Ciência Rural 39:9.

Machado, L.V., Rangel, O.J.P., Mendonça, E.S, Machado, R.V., Ferrari, J. 2014. Fertilidade e compartimentos da matéria orgânica sob diferentes sistemas de manejo. Coffee Science 9:289-299.

Mandiola, M., Studdert, G. A., Domínguez, G. F., Videla, C.C. 2011. Organic matter distribution in aggregate sizes of a mollisol under contrasting managements. Journal of Soil Science and Plant Nutrition 11:41-57.

Menezes, C.E.G. 2008. Integridade de paisagem, manejo e atributos do solo no médio Vale do Paraíba do Sul Pinheiral-RJ. 160f. (Tese de Doutorado) - Universidade Federal Rural do Rio de Janeiro, Seropédica, Brasil.

Nobre, C.P., Lázaro, M.L., Santo, M.M.E., Pereira, M.G., Berbara, R.L.L. 2015. Agregação, glomalina e carbono orgânico na chapada do Araripe, Ceará, Brasil. Caatinga 28:138 - 147.

Paula, R.R., Pereira, M.G., Machado, D.L. 2013. Atributos químicos e matéria orgânica em complexos florestais periodicamente inundados na restinga da Marambaia - RJ. CiênciaFlorestal 23: $529-538$.

Portugal. A. F., Juncksh, I., Schaefer, C. E. R. G., Neves, J. C. L. 2010. Estabilidade de agregados em argissolo sob diferentes usos, comparado com mata. Revista Ceres 57:545-553.

Rillig, M.C. 2004. Arbuscular mycorrhizae, glomalin and soil aggregation. CanadianJournalofsoil Science 28:355-363.

Santos, D. C.,Lima, C. L. R, Kunde, R. J, Carvalho, J. S., Abeijon, L. M., Pillon, C. N. 2012. Agregação e proteção física da matéria orgânica em planossolo háplico sob diferentes sistemas de manejo.Bioscience Journal 28:54-63.

Silva, C.F., Pereira, M.G., Miguel, D.L., Feitosa, J.C.F., Loss, A., Menezes, C.E.G., Silva, E.M.R. 2012. Carbono orgânico total, biomassa microbiana e atividade enzimática do solo de áreas agrícolas, florestais e pastagem no médio vale do paraíba do sul (RJ). RevistaBrasileira de Ciência do Solo36:1680-1689.

Silva, C.F., Pereira, M.G., Loss, A., Silva, E.M.R., Correia, M.E.F. 2006. Alteraçõesquímicas e físicas do solo em areas deagricultura no entorno do 
Parque Estadual da Serra do Mar, Ubatuba(SP). Revista de CiênciasAgrárias 46:9-28.

Soares, J.L.N, Espíndola, C.R., Castro, S.S.C. 2005. Alteração física e morfológica em solos cultivados sob sistema tradicional de manejo. Revista Brasileira de Ciência do Solo 29:10051014.

Swift, R. S. 1996. Organic matter characterization. In: Sparks, D. L., Page, A. L., Helmke, P. A., Loeppert, R. H., Soltanpour, P. N., Tabatabai, M. A., Johnston, C. T., Sumner, M. E. Methods of soil analysis. (ed.)Madison. p. 1011-1020.

Wright, S.F., Franke-Snyder, M., Morton, J.B., Upadhyaya, A. 1996. Time-course study and partial characterization of a protein on hyphae of arbuscular mycorrhizal fungi during active colonization of roots. Plant Soil 181:193-203.

Wright, S.F., Green, V.S., Cavigelli, M.A. 2007. Glomalin in aggregate size classes from three different farming systems. Soil Tillage Research 94:546-549.

Yeomans, J.C., Bremner, J.M. 1988. A rapid and precise method for routine determination of organic carbon in soil. Communications in Soil Science and Plant Analysis 19:1467-1476.

Yooder, R.E. 1936. A direct method of aggregate analyses soils and study of the physical nature of erosion losses. Journal of America Society Agronomy 28:337- 